\title{
Fc Receptor-Like Protein 2
}

National Cancer Institute

\section{Source}

National Cancer Institute. Fc Receptor-Like Protein 2. NCI Thesaurus. Code C117135.

Fc receptor-like protein 2 (508 aa, $\sim 56 \mathrm{kDa}$ ) is encoded by the human FCRL2 gene. This protein may play a role in the development of B-cells. 